\title{
Short communication: Effect of antioxidant supplementation on milk production, milk fat synthesis, and milk fatty acids in dairy cows when fed a diet designed to cause milk fat depression
}

\author{
J. P. Boerman, ${ }^{*}$ C. L. Preseault, ${ }^{*}$ J. Kraft, $†$ H. M. Dann, $\neq$ and A. L. Lock ${ }^{\star 1}$ \\ *Department of Animal Science, Michigan State University, East Lansing 48824 \\ †Department of Animal Science, University of Vermont, Burlington 05405 \\ $\ddagger$ William H. Miner Agricultural Research Institute, Chazy, NY 12921
}

\begin{abstract}
This study evaluated the effect of a blend of synthetic antioxidants on the yield of milk and milk components and milk fatty acid composition in dairy cows fed a diet designed to cause milk fat depression (MFD). We hypothesized that supplementing a synthetic antioxidant to diets with a high rumen unsaturated fatty acid load (RUFAL) would decrease the severity of MFD. Sixteen lactating Holstein cows (163 $\pm 47 \mathrm{~d}$ in milk), in a crossover design with two 21-d periods, were fed a corn silage and grass silage-based diet containing $15 \%$ distillers grains. The diet contained $34 \%$ neutral detergent fiber, $18 \%$ crude protein, $26 \%$ starch, and $4.3 \%$ total fatty acids (dry matter basis). Cows were fed the diet without supplementation (control; CON) or supplemented with $0.02 \%$ (dry matter basis) of a synthetic antioxidant (AOX; Agrado Plus, Novus International Inc., St. Charles, MO). Dry matter intake and milk yields were recorded daily. Milk samples were collected at the start of the study for baseline values and the end of each period (d 20-21) and analyzed for milk components and fatty acid composition. Dry matter intake and milk yield were unaffected by treatment and averaged 25.9 and $50.2 \mathrm{~kg} / \mathrm{d}$, respectively. Similarly, we observed no effect of treatment on yields of fat, protein, lactose, $3.5 \%$ fat-corrected milk, energycorrected milk, feed efficiency, body weight, or body condition score. Milk fat concentration and yield were both reduced by the high RUFAL diets. We observed a tendency for AOX to increase the concentration of milk fat and decrease the concentration of milk protein. Yields of de novo and preformed fatty acids were not affected by treatment, although we detected a trend for a slight increase in the yield of 16-carbon fatty acid for AOX compared with CON. Treatment had only minor effects on individual milk fatty acids, except for the
\end{abstract}

Received August 29, 2013.

Accepted October 23, 2013.

${ }^{1}$ Corresponding author: allock@msu.edu concentration and yield of linoleic acid, which were over $90 \%$ higher for AOX compared with CON. In conclusion, milk fat concentration and yield were reduced by a high RUFAL diet containing 15\% distillers grains; however, supplementation with AOX did not overcome the MFD induced by this diet.

Key words: antioxidant, biohydrogenation, unsaturated fatty acid, milk fat

\section{Short Communication}

Available evidence indicates that milk fat depression (MFD) is caused by shifts in the pathways of rumen biohydrogenation $(\mathbf{B H})$ of unsaturated FA and the passage of specific $\mathrm{BH}$ intermediates (e.g., trans-10, cis-12 18:2) out of the rumen that subsequently reduce milk fat synthesis in the mammary gland (Bauman et al., 2011). An increase in rumen unsaturated FA load (RUFAL) is a well-established risk factor for MFD (e.g., He et al., 2012). Previous work suggests that a high level of vitamin $\mathrm{E}$ ( $\alpha$-tocopheryl acetate) has the potential to maintain "normal" $\mathrm{BH}$ pathways, thereby possibly reducing the production of $\mathrm{BH}$ intermediates that cause MFD (Focant et al., 1998; Pottier et al., 2006). Results from studies supplementing synthetic antioxidants in dairy cows have been mixed; VázquezAñón et al. (2008) reported improvements in milk fat yield when a synthetic antioxidant was supplemented in diets containing $2 \%$ soybean oil. However, He and Armentano (2011) supplemented the same synthetic antioxidant and found no effect on DMI, milk yield, or milk components with diets containing $5 \%$ vegetable oils varying in their degree of unsaturation. Therefore, our objective was to examine the effect of a blend of synthetic antioxidants, Agrado Plus (Novus International, Inc., St. Charles, MO), on the yields of milk and milk components and milk FA profile in cows fed a high RUFAL diet, containing 15\% dried distillers grains (DDG). We hypothesized that dietary antioxidant would alleviate the negative effect of the high RUFAL diet and minimize shifts in $\mathrm{BH}$ pathways in the rumen, 
Table 1. Ingredient and nutrient composition of the experimental diet

\begin{tabular}{|c|c|}
\hline Item & $\operatorname{Diet}^{1}$ \\
\hline \multicolumn{2}{|l|}{ Ingredient, $\%$ of DM } \\
\hline Corn silage & 33.2 \\
\hline Grass silage & 13.1 \\
\hline Alfalfa hay & 3.5 \\
\hline Corn meal & 13.1 \\
\hline Dried distillers grains & 15.1 \\
\hline Soybean meal & 6.0 \\
\hline Soybean hulls & 4.6 \\
\hline Mineral mix $^{2}$ & 11.4 \\
\hline \multicolumn{2}{|l|}{ Nutrient composition } \\
\hline DM, \% & 47.7 \\
\hline NDF, $\%$ of DM & 34.2 \\
\hline Starch, \% of DM & 25.8 \\
\hline $\mathrm{CP}, \%$ of $\mathrm{DM}$ & 17.8 \\
\hline Total FA, \% of DM & 4.3 \\
\hline \multicolumn{2}{|c|}{ FA concentration, $g / 100 \mathrm{~g}$ of total FA } \\
\hline $14: 0$ & 0.5 \\
\hline $16: 0$ & 16.9 \\
\hline $16: 1$ cis-9 & 0.6 \\
\hline $18: 0$ & 4.8 \\
\hline $18: 1$ cis-9 & 23.6 \\
\hline $18: 2$ cis- 9, cis- 12 & 40.8 \\
\hline $18: 3$ cis-9, cis- 12, cis- 15 & 6.1 \\
\hline$\Sigma$ Others & 6.7 \\
\hline RUFAL $^{3}$ & 70.5 \\
\hline
\end{tabular}

${ }^{1}$ Agrado Plus (Novus International Inc., St. Charles, MO) was added to the AOX diet at $0.02 \%$ of DM.

${ }^{2}$ Mineral mix contained $22.7 \%$ wheat middlings, $17.5 \%$ molasses, $14.0 \%$ calcium carbonate, $8.9 \%$ beef blood meal, $9.4 \%$ sodium bicarbonate, $7.6 \%$ partially hydrogenated tallow, 6.3\% Amino Plus (Ag Processing Inc., Hastings, NE), 4.7\% salt, $3.2 \%$ calcium sulfate dihyd, $2.8 \%$ urea, $1.7 \%$ magnesium oxide, $0.4 \%$ Cargill 885 Se 0.06 (Cargil Inc., Minneapolis, MN), 0.3\% Alimet (Novus International Inc.), $0.2 \%$ Cargill Dairy ADE 5487 (Cargill Inc.), and 0.3\% Mintrex R (Novus International Inc.).

${ }^{3}$ Rumen unsaturated fatty acid load. thereby reducing the formation of MFD-related $\mathrm{BH}$ intermediates and decreasing the risk of MFD.

Sixteen lactating Holstein cows (6 primiparous and 10 multiparous), averaging $163 \pm 47$ DIM, $46.7 \pm 1.8 \mathrm{~kg} / \mathrm{d}$ milk yield, and $3.8 \pm 0.01 \%$ milk fat at the beginning of the experiment, were used in a crossover design with 2 consecutive 21-d periods. Cows were blocked based on milk yield and milk fat concentration. Cows were housed in tiestalls equipped with individual feed boxes and fed a diet formulated according to NRC (2001) recommendations (Table 1 ). Water was available ad libitum in each stall. Cows were milked 3 times a day at 8-h intervals.

The high RUFAL diet contained 15\% DDG (DM basis; Table 1). Cows were either fed the diet without supplementation (control; CON) or supplemented with $0.02 \%$ (DM basis) of Agrado Plus (AOX). The Agrado Plus was blended into a separate mineral mix for the AOX treatment. Diets were fed once a day (1000 h) for ad libitum intake and feed intake was recorded daily. Individual feed ingredients were analyzed for chemical composition (Cumberland Valley Analytical Services Inc., Hagerstown, MD; Table 1). Body weight and BCS (Wildman et al., 1982) were measured at the end of each period. Dry matter intake and milk yield were recorded daily and milk sampled at each milking on d 20 and 21 of each period. Individual milk samples were analyzed for fat, true protein, and lactose concentrations by mid-infrared spectroscopy (AOAC, 1990; method 972.160) by Dairy One (Ithaca, NY) and for

Table 2. Dry matter intake, milk production, milk components, feed efficiency, BW, and BCS for cows fed treatment diets $(\mathrm{n}=16)$

\begin{tabular}{|c|c|c|c|c|}
\hline \multirow[b]{2}{*}{ Variable } & \multicolumn{2}{|c|}{ Treatment $^{1}$} & \multirow[b]{2}{*}{ SEM } & \multirow{2}{*}{$\begin{array}{c}\text { Treatment } \\
P \text {-value }\end{array}$} \\
\hline & $\mathrm{CON}$ & $\mathrm{AOX}$ & & \\
\hline $\mathrm{DMI}, \mathrm{kg} / \mathrm{d}$ & 25.7 & 26.0 & 0.50 & 0.49 \\
\hline \multicolumn{5}{|l|}{ Milk yield, $\mathrm{kg} / \mathrm{d}$} \\
\hline Milk & 50.2 & 50.2 & 1.28 & 0.96 \\
\hline $3.5 \% \mathrm{FCM}^{2}$ & 48.0 & 48.9 & 1.20 & 0.34 \\
\hline $\mathrm{ECM}^{3}$ & 48.1 & 48.6 & 1.15 & 0.53 \\
\hline \multicolumn{5}{|l|}{ Milk components } \\
\hline Fat, $\mathrm{kg} / \mathrm{d}$ & 1.62 & 1.68 & 0.05 & 0.18 \\
\hline Fat, $\%$ & 3.27 & 3.39 & 0.09 & 0.07 \\
\hline Protein, kg/d & 1.48 & 1.46 & 0.04 & 0.37 \\
\hline Protein, \% & 2.95 & 2.91 & 0.04 & 0.06 \\
\hline Lactose, $\mathrm{kg} / \mathrm{d}$ & 2.48 & 2.49 & 0.06 & 0.81 \\
\hline Lactose, \% & 4.95 & 4.98 & 0.04 & 0.25 \\
\hline Feed efficiency (ECM/DMI) & 1.88 & 1.87 & 0.03 & 0.82 \\
\hline $\mathrm{BW}, \mathrm{kg}$ & 688 & 692 & 17.4 & 0.16 \\
\hline BCS & 3.12 & 3.10 & 0.08 & 0.61 \\
\hline
\end{tabular}

${ }^{1}$ Treatments were high rumen unsaturated FA load diets containing 15\% dried distillers grains either without supplementation (CON) or supplemented with a synthetic antioxidant (AOX; Agrado Plus, Novus International Inc., St. Charles, MO) at $0.02 \%$ of diet DM.

${ }^{2} 3.5 \% \mathrm{FCM}=[(0.4324 \times \mathrm{kg}$ of milk $)+(16.216 \times \mathrm{kg}$ of milk fat $)]$.

${ }^{3} \mathrm{ECM}=[(0.327 \times \mathrm{kg}$ of milk $)+(12.95 \times \mathrm{kg}$ of milk fat $)+(7.20 \times \mathrm{kg}$ of milk protein $)]$ (Tyrrell and Reid, $1965)$. 
Table 3. Milk fatty acid concentrations of cows fed treatment diets $(\mathrm{n}=16)$

\begin{tabular}{|c|c|c|c|c|}
\hline \multirow[b]{2}{*}{$\mathrm{FA}, \mathrm{g} / 100 \mathrm{~g}$} & \multicolumn{2}{|c|}{ Treatment $^{1}$} & \multirow[b]{2}{*}{ SEM } & \multirow{2}{*}{$\begin{array}{c}\text { Treatment } \\
P \text {-value }\end{array}$} \\
\hline & $\mathrm{CON}$ & $\mathrm{AOX}$ & & \\
\hline \multicolumn{5}{|l|}{ Source of $\mathrm{FA}^{2}$} \\
\hline De novo & 21.1 & 21.3 & 0.47 & 0.51 \\
\hline Mixed & 27.9 & 28.3 & 0.66 & 0.31 \\
\hline \multirow{2}{*}{\multicolumn{5}{|c|}{ Selected individual $\mathrm{FA}^{3}$}} \\
\hline & & & & \\
\hline $4: 0$ & 2.71 & 2.75 & 0.10 & 0.65 \\
\hline $6: 0$ & 1.66 & 1.68 & 0.07 & 0.68 \\
\hline $8: 0$ & 0.95 & 0.96 & 0.05 & 0.72 \\
\hline 10:0 & 2.26 & 2.28 & 0.10 & 0.80 \\
\hline $12: 0$ & 2.69 & 2.73 & 0.09 & 0.70 \\
\hline $14: 0$ & 9.81 & 9.95 & 0.18 & 0.25 \\
\hline $14: 1$ cis-9 & 0.97 & 0.98 & 0.07 & 0.83 \\
\hline $16: 0$ & 26.4 & 26.8 & 0.61 & 0.20 \\
\hline $16: 1$ cis-9 & 1.53 & 1.50 & 0.11 & 0.72 \\
\hline 18:0 & 10.8 & 10.8 & 0.39 & 0.90 \\
\hline $18: 1$ trans -4 & 0.03 & 0.03 & 0.001 & 1.00 \\
\hline $18: 1$ trans -5 & 0.03 & 0.02 & 0.001 & 0.18 \\
\hline $18: 1$ trans $-6-8$ & 0.52 & 0.49 & 0.02 & 0.07 \\
\hline 18:1 trans -9 & 0.43 & 0.41 & 0.01 & 0.04 \\
\hline 18:1 trans -10 & 1.40 & 1.12 & 0.24 & 0.14 \\
\hline 18:1 trans -11 & 2.57 & 2.53 & 0.15 & 0.76 \\
\hline 18:1 trans -12 & 0.63 & 0.61 & 0.02 & 0.13 \\
\hline $18: 1$ cis-9 & 22.0 & 21.7 & 0.54 & 0.38 \\
\hline $18: 2$ cis -9, cis- 12 & 1.32 & 2.60 & 0.25 & 0.01 \\
\hline 18:2 cis-9,trans- 11 & 1.25 & 1.20 & 0.07 & 0.39 \\
\hline $18: 2$ trans -10, cis -12 & 0.01 & 0.01 & 0.002 & 0.30 \\
\hline $18: 3$ cis -9, cis- 12, cis -15 & 0.34 & 0.32 & 0.01 & 0.04 \\
\hline
\end{tabular}

${ }^{1}$ Treatments were high rumen unsaturated FA load diets containing 15\% dried distillers grains either without supplementation (CON) or supplemented with a synthetic antioxidant (AOX; Agrado Plus, Novus International Inc., St. Charles, MO) at $0.02 \%$ of diet DM.

${ }^{2}$ De novo FA originate from mammary de novo synthesis ( $<16$ carbons), preformed FA originate from extraction from plasma (>16 carbons), and mixed FA originate from both sources (C16:0 and C16:1 cis-9).

${ }^{3} \mathrm{~A}$ total of approximately 70 individual FA were quantified and used for calculations (summation by source); only select FA are reported in the table.

FA composition by GLC (Lock et al., 2013). Data were analyzed as a mixed model using the fit model procedure of JMP (version 9.0.2, SAS Institute Inc., Cary, NC). The model included the fixed effects of period and treatment and the random effect of cow. Preliminary $3.5 \%$ FCM yield from the first day of the trial was used as a covariate and was removed from the model when $P \geq 0.20$. Period by treatment interactions were nonsignificant and therefore removed from the model. Least squares means from $\mathrm{CON}$ and $\mathrm{AOX}$ are reported with significance declared at $P \leq 0.05$ and trends at $P$ $\leq 0.10$.

Dry matter intake $(P=0.49)$ and milk yield $(P=$ $0.96)$ were unaffected by treatment and averaged 25.9 and $50.2 \mathrm{~kg} / \mathrm{d}$, respectively (Table 2). Similarly, yields of $3.5 \%$ FCM and ECM, feed efficiency, BW, and BCS were also unaffected by treatment (all $P>0.16$ ). Milk fat concentration and yield were both reduced by the high RUFAL diets compared with pretrial values. Milk fat concentration was $3.27 \%$ for CON and $3.39 \%$ for AOX $(P=0.07)$, and milk fat yield was $1.62 \mathrm{~kg} / \mathrm{d}$ for CON and $1.68 \mathrm{~kg} / \mathrm{d}$ for AOX $(P=0.18$, Table 2$)$. Similarly, Leonardi et al. (2005) reported a linear decrease in milk fat concentration when DDG were fed from 0 to $15 \%$ of diet DM. Hollmann et al. (2011), in a meta-analysis of DDG feeding in lactating dairy cattle, reported that milk fat concentration results were inconsistent, but there was typically a negative response to feeding DDG when control cows averaged above $3.6 \%$ milk fat. This is in agreement with our findings because, at the start of our study, milk fat concentration was 3.8\%. Vázquez-Añón et al. (2008) reported an increase in milk fat yield when the same synthetic antioxidant as used in the current study was supplemented in diets containing $2 \%$ fresh or oxidized soybean oil, with no significant difference between the 2 fat types. However, He and Armentano (2011) reported no difference in milk fat concentration and yield when the same synthetic antioxidant was supplemented in diets containing $5 \%$ vegetable oil varying in the extent of unsaturation. In the current study, we observed a trend $(P=0.07)$ for greater milk fat concentration for cows 
Table 4. Milk fatty acid yields of cows fed treatment diets $(\mathrm{n}=16)$

\begin{tabular}{|c|c|c|c|c|}
\hline \multirow[b]{2}{*}{ FA yield, $\mathrm{g} / \mathrm{d}$} & \multicolumn{2}{|c|}{ Treatment $^{1}$} & \multirow[b]{2}{*}{ SEM } & \multirow{2}{*}{$\begin{array}{c}\text { Treatmen } \\
P \text {-value }\end{array}$} \\
\hline & $\mathrm{CON}$ & AOX & & \\
\hline \multicolumn{5}{|l|}{$\overline{\text { Source of } \mathrm{FA}^{2}}$} \\
\hline De novo & 311 & 325 & 13.8 & 0.23 \\
\hline Mixed & 411 & 431 & 19.2 & 0.07 \\
\hline Preformed & 745 & 763 & 20.6 & 0.40 \\
\hline \multicolumn{5}{|l|}{ Selected individual $\mathrm{FA}^{3}$} \\
\hline $4: 0$ & 40.0 & 42.0 & 2.16 & 0.29 \\
\hline $6: 0$ & 24.6 & 25.7 & 1.55 & 0.36 \\
\hline 8:0 & 14.1 & 14.8 & 0.95 & 0.42 \\
\hline 10:0 & 33.4 & 34.8 & 2.06 & 0.45 \\
\hline $12: 0$ & 39.8 & 41.5 & 2.08 & 0.35 \\
\hline $14: 0$ & 144 & 151 & 5.55 & 0.12 \\
\hline $14: 1$ cis-9 & 14.3 & 14.9 & 1.16 & 0.31 \\
\hline $16: 0$ & 388 & 409 & 18.1 & 0.06 \\
\hline $16: 1$ cis-9 & 22.6 & 22.9 & 1.86 & 0.81 \\
\hline $18: 0$ & 158 & 165 & 6.84 & 0.25 \\
\hline $18: 1$ trans -4 & 0.45 & 0.45 & 0.02 & 0.95 \\
\hline $18: 1$ trans -5 & 0.37 & 0.36 & 0.02 & 0.70 \\
\hline $18: 1$ trans $-6-8$ & 7.61 & 7.46 & 0.32 & 0.57 \\
\hline $18: 1$ trans -9 & 6.26 & 6.25 & 0.17 & 0.93 \\
\hline $18: 1$ trans -10 & 19.9 & 16.9 & 3.29 & 0.22 \\
\hline $18: 1$ trans -11 & 37.6 & 38.6 & 2.60 & 0.70 \\
\hline $18: 1$ trans -12 & 9.23 & 9.26 & 0.28 & 0.92 \\
\hline $18: 1$ cis-9 & 320 & 328 & 9.62 & 0.42 \\
\hline $18: 2$ cis- 9, cis- 12 & 19.8 & 39.3 & 3.82 & 0.003 \\
\hline $18: 2$ cis-9,trans-11 & 18.2 & 18.2 & 1.09 & 0.99 \\
\hline $18: 2$ trans -10 . cis -12 & 0.16 & 0.14 & 0.03 & 0.52 \\
\hline $18: 3$ cis -9, cis- 12, cis -15 & 4.89 & 4.89 & 0.15 & 0.99 \\
\hline
\end{tabular}

${ }^{1}$ Treatments were high rumen unsaturated FA load diets containing $15 \%$ dried distillers grains either without supplementation (CON) or supplemented with a synthetic antioxidant (AOX; Agrado Plus, Novus International Inc., St. Charles, MO) at $0.02 \%$ of diet DM.

${ }^{2}$ De novo FA originate from mammary de novo synthesis ( $<16$ carbons), preformed FA originate from extraction from plasma (>16 carbons), and mixed FA originate from both sources (C16:0 and C16:1 cis-9).

${ }^{3} \mathrm{~A}$ total of approximately 70 individual FA were quantified and used for calculations (summation by source); only select FA are reported in the table.

fed AOX compared with CON but no difference in fat yield $(P=0.18)$. In general, the effect of antioxidants on rumen $\mathrm{BH}$ is not well understood. Thus, the reasons for differences in results when using the same synthetic antioxidant require further investigation. Given that the synthetic antioxidant in the current study was only supplemented in the diet at the same time as the high RUFAL diet was first fed may have limited its potential effects on rumen $\mathrm{BH}$. It might be necessary to provide such an antioxidant before a MFD challenge to realize potential benefits on minimizing changes in $\mathrm{BH}$ pathways and risk of MFD.

We observed no effect of treatment on the yield of milk protein $(P=0.37)$ or lactose $(P=0.81)$. Although milk lactose concentration was not different $(P=0.25)$, we observed a trend for milk protein concentration to be slightly lower with AOX compared with CON (2.91 vs. $2.95 ; P=0.06)$. Vázquez-Añón et al. (2008) reported similar results.

The concentration of individual FA in milk for both $\mathrm{CON}$ and AOX revealed a clear shift in $\mathrm{BH}$ pathways associated with MFD (Table 3). This was indicated by the relatively high concentration of preformed FA $(>16$ carbons) compared with de novo FA ( $<16$ carbons) and FA originating from mixed sources (16-carbon FA), which is the characteristic response observed when fat synthesis is reduced in the mammary gland of dairy cattle (e.g., Harvatine and Bauman, 2011). However, we did not observe an effect of treatment on the concentration of FA based on source (Table 3). Although the yields of both de novo and preformed FA were not affected by treatment, we did observe a trend $(P=0.07)$ for a slight increase $(5 \%)$ in the yield of 16-carbon FA for AOX compared with CON (Table 4). The concentration of trans-10 18:1 in milk fat is a well-established marker for shifts in BH pathways indicative of MFD, and a robust relationship exists between its production in the rumen and milk fat synthesis (Shingfield et al., 2006; Lock et al., 2007). We observed relatively high levels of trans-10 18:1 in milk fat in both CON and AOX, although concentrations were not different across treatments $(P=0.14)$. Vázquez-Añón et al. 
(2008) proposed that changes in microbial populations toward more complete $\mathrm{BH}$ would reduce the likelihood of MFD. Results from the current study provide no support for an effect of AOX on BH rates or pathways. Further research on the negative effects of unsaturated FA on bacterial metabolism in general and the potential of antioxidants to mitigate these negative effects is warranted.

Of interest, however, both the concentration $(P=$ $0.01)$ and yield $(P=0.003)$ of linoleic acid (cis-9, cis-12 18:2) were over $90 \%$ higher for AOX compared with CON. Similarly, Wang et al. (2010) reported an increased concentration of linoleic acid in milk fat when antioxidants were supplemented in early lactation, and Vázquez-Añón et al. (2008) reported slightly higher concentrations of oleic acid (cis-9 18:1) in milk with antioxidant supplementation. Potentially, AOX may have reduced the overall extent of $\mathrm{BH}$ of linoleic acid or altered its metabolism postabsorption, or both. Alternatively, Andrews et al. (2006) reported that the same synthetic antioxidant as used in the current study could improve fat stability and preservation of FA in feed ingredients used in ruminant rations, possibly increasing overall linoleic acid availability in the diet and delivery postrumen.

In conclusion, milk fat concentration and yield were both reduced by a high RUFAL diet containing $15 \%$ DDG; however, supplementation with AOX did not overcome the MFD induced by this diet. Further work is required to determine whether the initiation of antioxidant supplementation before a MFD challenge would have a different effect on rumen BH and risk of MFD.

\section{ACKNOWLEDGMENTS}

We acknowledge Novus International Inc. (St. Charles, MO), the University of Vermont Robert L. Bickford Jr. Keystone Award, and Michigan State University AgBioResearch for financial support. We also thank M. Vázquez-Añón, G. Bowman, and G. Zanton from Novus International Inc., and R. J. Grant, C. S. Ballard, M. P. Carter, and the Miner Institute (Chazy, $\mathrm{NY}$ ) research and dairy staff for their assistance with this study.

\section{REFERENCES}

Andrews, J., M. Vázquez-Añón, and G. Bowman. 2006. Fat stability and preservation of fatty acids with AGRADO antioxidant in feed ingredients used in ruminant rations. J. Dairy Sci. 89(Suppl. 1):60. (Abstr.)

AOAC (Association of Official Analytical Chemists). 1990. Official Methods of Analysis. 15th ed. Association of Official Analytical Chemists, Arlington, VA.

Bauman, D. E., K. J. Harvatine, and A. L. Lock. 2011. Nutrigenomics, rumen-derived bioactive fatty acids, and the regulation of milk fat synthesis. Annu. Rev. Nutr. 31:299-319.

Focant, M., E. Mignolet, M. Marique, F. Clabots, T. Breyne, D. Dalemans, and Y. Larondelle. 1998. The effect of vitamin E supplementation of cow diets containing rapeseed and linseed on the prevention of milk fat oxidation. J. Dairy Sci. 81:1095-1101.

Harvatine, K. J., and D. E. Bauman. 2011. Characterization of the acute lactational response to trans-10, cis-12 conjugated linoleic acid. J. Dairy Sci. 94:6047-6056.

He, M., and L. E. Armentano. 2011. Effect of fatty acid profile in vegetable oils and antioxidant supplementation on dairy cattle performance and milk fat depression. J. Dairy Sci. 94:2481-2491.

He, M., K. L. Perfield, H. B. Green, and L. E. Armentano. 2012. Effect of dietary fat blend enriched in oleic or linoleic acid and monensin supplementation on dairy cattle performance, milk fatty acid profiles, and milk fat depression. J. Dairy Sci. 95:1447-1461.

Hollmann, M., M. S. Allen, and D. K. Beede. 2011. Diet fermentability influences lactational performance responses to corn distillers grains: A meta-analysis. J. Dairy Sci. 94:2007-2021.

Leonardi, C., S. Bertics, and L. E. Armentano. 2005. Effect of increasing oil from distillers grains or corn oil on lactation performance. J. Dairy Sci. 88:2820-2827.

Lock, A. L., C. L. Preseault, J. E. Rico, K. E. DeLand, and M. S. Allen. 2013. Feeding a C16:0-enriched fat supplement increased the yield of milk fat and improved conversion of feed to milk. J. Dairy Sci. 96:6650-6659.

Lock, A. L., C. Tyburczy, D. A. Dwyer, K. J. Harvatine, F. Destaillats, Z. Mouloungui, L. Candy, and D. E. Bauman. 2007. Trans-10 octadecenoic acid does not reduce milk fat synthesis in dairy cows. J. Nutr. 137:71-76.

NRC. 2001. Nutrient Requirements of Dairy Cattle. 7th rev. ed. National Acad. Press, Washington, DC.

Pottier, J., M. Focant, C. Debier, G. De Buysser, C. Goffe, E. Mignolet, E. Froidmont, and Y. Larondelle. 2006. Effect of dietary vitamin $\mathrm{E}$ on rumen biohydrogenation pathways and milk fat depression in dairy cows fed high-fat diets. J. Dairy Sci. 89:685-692.

Shingfield, K. J., C. K. Reynolds, G. Hervàs, J. M. Griinari, A. S. Grandison, and D. E. Beever. 2006. Examination of the persistency of milk fatty acid composition responses to fish oil and sunflower oil in the diet of dairy cows. J. Dairy Sci. 89:714-732.

Tyrrell, H. F., and J. T. Reid. 1965. Prediction of the energy value of the milk. J. Dairy Sci. 48:1215-1223.

Vázquez-Añón, M., J. Nocek, G. Bowman, T. Hampton, C. Atwell, P. Vázquez, and T. Jenkins. 2008. Effects of feeding a dietary antioxidant in diets with oxidized fat on lactation performance and antioxidant status of the cow. J. Dairy Sci. 91:3165-3172.

Wang, Y. M., J. H. Wang, C. Wang, B. Chen, J. X. Liu, H. Cao, F. C. Guo, and M. Vázquez-Añón. 2010. Effect of different rumen-inert fatty acids supplemented with a dietary antioxidant on performance and antioxidative status of early-lactation cows. J. Dairy Sci. 93:3738-3745

Wildman, E. E., G. M. Jones, P. E. Wagner, and R. L. Bowman. 1982. A dairy cow body condition scoring system and its relationship to selected production characteristics. J. Dairy Sci. 65:495-501. 